\title{
整
}

\section{Heretical baptism in debate}

\author{
A. van de Beek \\ Faculty of Theology \\ University of Stellenbosch \\ STELLENBOSCH \\ E-mail: beekavd@xs4all.nl
}

\section{Abstract \\ Heretical baptism in debate}

It is generally stated that acceptance of heretics in the Catholic Church without baptism has always been normal use in the church and has been confirmed by general councils. The only exceptions would be some groups in North Africa in the third through the fifth century. This opinion is mainly based on Augustine's "De baptismo". The author of this article argues that Augustine is historically incorrect and systematically weak in this respect. Baptism of converted heretics was normal, except from Rome, and even the council of Nicea confirms that normal use. The bishop of Rome in the fifties of the third century, Stephan, had his own reasons for refusing to rebaptise heretics. Augustine's view that the baptismal rite and its salutary effect by faith can be received separately is a break with early Christian ecclesiology and its impact on the Western Church has been enormous.

\section{Opsomming}

\section{Debat oor ketterdoop}

Dit word algemeen gestel dat die aanvaarding van ketters in die Katolieke Kerk sonder die doop altyd normale gebruik was en dat dit deur konsilies bevestig sou wees. Die enigste uitsonderings sou sekere groepe in Noord-Afrika gedurende die derde tot vyfde eeu wees. Hierdie opinie is hoofsaaklik gebaseer op Augustinus se "De baptismo". Die outeur van hierdie artikel toon aan dat Augustinus histories inkorrek en sistematies swak was in hierdie opsig. Die doop van bekeerde ketters was normaal, behalwe in Rome. Selfs die Konsilie van Nicea bevestig hierdie normale gebruik. Die biskop van Rome gedurende die vyftigerjare van die derde eeu, Stephan, het sy eie redes gehad waarom hy geweier het om ketters te herdoop. Augus- 
tinus se siening dat die dooprite en die doop se heilsame effek deur geloof afsonderlik ontvang kon word, is in stryd met vroeë Christelike ekklesiologie en die impak daarvan op die Westerse Kerk was enorm.

\section{Introduction}

The Synod of Arles decided that baptism administered by heretics was valid. That is what I remember from my theological education. In the third century there was a fierce conflict between Cyprian of Carthage and Stephen of Rome about the issue. Stephen excommunicated people who rebaptised those who came to the church from heretical communities. Yet a century later everything was settled. As Nolet (1926:74) in his church history says: "Pope Stephen's decision was gradually accepted within the whole church, and it is universally accepted since the beginning of the fourth century."

Reality is more complicated. As soon as one reads more on the issue, it is far more complex than the residue contained within a student's memory or a simple textbook on church history. For the topic was not at all settled at the beginning of the fourth century. Although the synod of Arles condemned the Donatists' rebaptism (Denzinger \& Schönmetzer, 1967:123), they did not give in, and - by consequence - a burning conflict ravaged the church in Africa during the fourth century. Moreover, Stephen did not provide much theology to support his decision, so that it appeared to be more of a use of power by the bishop of Rome. It was Augustine who contested the Donatists, both with force and by offering a theological underpinning against baptising heretics. It is his theology on baptism that has become dominant in the West, and it is precisely this theology that opened the door for the schisms and denominational divisions that we are confronted with today. Therefore, it will be interesting to see what was at stake for the participants of a debate that reached much further than a conflict between Rome and some African bishops.

I will begin with a short display of Augustine's position, and subsequently, I will deal with the different regions of the church in the third century. After that I will consider the councils that are relevant for the topic. 


\section{Augustine}

Augustine develops his thought on baptism in his clash with the Donatists - especially in his writing, De baptismo. The Donatists were still strong in Africa, even after a century of conflicts with the Catholic Church. Augustine wanted to end the counter church and its ongoing attraction for more radical people among the Catholics once and for all. He did so (besides suppression by the power of the government) by four arguments: calling on Cyprian, on custom, on the decision of a council, and by developing a theology of baptism.

The Donatists claimed Cyprian and argued that he rejected baptism by heretics. Augustine could not deny this, but he adds that Cyprian never left the Catholic Church, even though the conflict was very fierce. So the Donatists' call on Cyprian was futile - unless they mimic what Cyprian did and maintain the unity of the church (e.g. Augustinus, De baptismo 1.18.28; 2.6.7; 2.13.18; 3.1.1; 5.1.1).

Further, there is a difference, according to Augustine, between the time of Cyprian and his own. Cyprian was free to have his own opinion because there was not yet a decision of a universal council in that time. This freedom was not allowed after the decision was made in Arles in 314 (Augustinus, De baptismo 1.18.27 ff.). Now that the universal church has decided that heretics may not be rebaptised, the Christians in Africa should also comply with that decision. They cannot call on their own regional councils or a mere correspondence with some bishops "in far distant lands beyond the sea", as Augustine labels Cyprian's correspondence with Firmilian of Caesarea (Augustinus, De baptismo 2.2.2). ${ }^{1}$ Local synods and developing opinions by letters can always be overruled by a universal council, as is the case here.

Augustine argues that this council was in line with tradition from the beginning. Rebaptising heretics who converted to the church was a new action in third century Africa. It was invented by Bishop Agrippinus of Carthage around 215 (Augustinus, De baptismo 2.7.12; $2.8 .13 ; 2.9 .14 ; 3.2 .3 ; 3.12 .17$ ), and the universal church never accepted it.

1 Translations of the fathers in English are taken from Ante-Nicene fathers (ANF) and Nicene and post-Nicene fathers of the Christian Church (NPNF) texts that are not available in these series are translated by the author of this article. 
Augustine's theological foundation of accepting the baptism of heretics is that baptism is not dependent on the receiver nor on the administrator. If that were the case, one could never be certain whether one was really baptised. It is not possible to know whether the bishop who baptised you is a deceiver who does not share the communion of the Holy Spirit, even if he is a bishop of the Catholic Church. He might be a murderer, or he might be covetous - while nobody knows about his secret life (Augustinus, De baptismo 4.18.26-20, 28; 5.11.12-13, 14). You can only be certain of your salvation if baptism is independent from the administrator. And it is independent because baptism is owned by Christ Himself. He is the guarantee that it is valid (Augustinus, De baptismo 5.15.19; 5.23.31).

If somebody is baptised by a heretic, baptism is valid, but the people involved are wrong. It is lawful, but not lawfully given (Augustinus, De baptismo 5.7.8; 5.8.9). Therefore, it has no effect as long as the baptised person dwells in heresy - just as baptism in the Catholic Church does not save you if you lead a covetous life.

Augustine thus makes a distinction between the rite of baptism and its use and effects. The rite is valid, but not legally used, and thus you cannot receive its gains unless you will use it legally: becoming a Catholic and not living in sin. By doing so, he makes baptism independent of the people involved and its effects fully dependent on the receiver. It is this doctrine on baptism that shaped Western baptismal thought. Precisely because of this impact, it is interesting to investigate how solid the ground is whereon Augustine built. We will do this investigation by considering the history before him.

\section{Cyprian}

Cyprian is a key theologian in the debate between Augustine and the Donatists. Of course, Augustine is right when he argues that their appeal to Cyprian is of no avail because Cyprian never drew the conclusion that they have drawn - to break communion with Rome. It is, however, more interesting to look at Augustine's own theological underpinning in relation to Cyprian. Augustine's doctrine of baptism has two focal points: the baptismal rite and the status of persons in faith. In order to be effective, both must be right, but either can exist independently.

Cyprian begins with a totally different paradigm - with communion. He does not focus on individual persons, but on the community of the church and the unity of all its aspects (cf. Van de Beek, 2009). 
That does not only mean that you cannot separate baptism and its legal use, but also that baptism is not dependent on the individual administrator. It is dependent on Christ - Cyprian will agree with Augustine - but Christ is present in the community of the church. The individual administrator is not the guarantee of baptism, but the community wherein it happens. If the community is right, baptism is right; if the community is wrong, baptism is also wrong - in all its aspects - and therefore, it is no baptism at all. Since the community of heretics is wrong by their very heresy, they cannot baptise, and since the community of the church is right by their very catholicity and unity, her baptism is right and salutary.

Cyprian focuses on the community; Augustine focuses on the individual. If Augustine would have made the administrating community the basis of his argument, he would have saved himself from the need to think about such strange matters as the validity of a baptism rite which is executed by a comic in a theatre (Augustinus, De baptismo 7.53.101 ff.). But he could not, because at the very moment he would do so, he lost a major argument against the Donatists.

Actually, Augustine must have been aware that his foundation was not very strong. His writing, De baptismo, not only continuously repeats the same arguments (cf. Augustinus, De baptismo 6.1.1) like preachers do when they think they cannot readily convince their congregation - but he explicitly admits that he would have been convinced by Cyprian's arguments if a custom of the universal tradition was not against him (Augustinus, De baptismo 3.4.6). Even the decision of Arles is a side argument compared to that. Thus the burden of evidence of Augustine's position is first and foremost on custom. That challenges us to trace this custom in the universal church as far as the data allow us - even more so because custom is Stephen of Rome's main argument against Cyprian and his other opponents in the heated conflicts of the third century. ${ }^{2}$

The anonymous writing, De rebaptismate, supports Stephen's view that accepting heretics without baptism is an old tradition. It refers to the fact that

... according to the most ancient custom and ecclesiastical tradition, it
would suffice, after that baptism which they have received outside the
Church indeed, but still in the name of Jesus Christ our Lord, that only
hands should be laid upon them by the bishop for their reception of
the Holy Spirit (Anon. [2007]: ch. 1, cf. also ch. 15).

De rebaptismate is a very interesting book, but its status is unclear. Most scholars presently date it in the 250 s, and I think this is right. I do not think its 


\section{Africa}

Because the focus is especially on Africa, we will begin our research there. Augustine states that it was a new finding of Agrippinus. Cyprian (Epistola 70, 4 = CCSL 71.4.1; Epistola 72, $3=$ CCSL 73.3.1) also refers to Agrippinus. He recalls that Agrippinus and his synod decided to baptise heretics when they entered the Catholic Church. This reference, however, does not mean the synod's decision was something new. In 256, the synod of Carthage, presided over by Cyprian himself, also decided to baptise heretics, and they knew that it was not a new occurrence. They claimed it was truth, but it was truth with an existing use in the African church. Therefore, Agrippinus' decision could also be a confirmation of existing custom.

That the baptism by heretics was not acknowledged before Agrippinus is clear from a passage in Tertullian's De baptismo, a text that was written in Tertullian's orthodox period. He writes:

Heretics ... and we have not the same God, nor one - that is, the same - Christ. And therefore their baptism is not one with ours either, because it is not the same; a baptism which, since they have it not duly, doubtless they have not at all; nor is that capable of being counted which is not had. Thus they cannot receive it either, because they have it not. (Tertullianus, De baptismo 15.2; cf. also De praesciptione haereticorum 29.3 and De pudicitia 19.)

place of origin can be Africa, precisely because of its referral to custom; thus, Rome will be more probable. It makes a strong distinction between baptism and confirmation, whereby the latter is more decisive than the former (Anon. ch. 6). After a baptism by heretics, a Catholic confirmation can supply what was missing (Anon. ch. 5 ff., 10, 14).

De rebaptismate cannot be considered as an earlier stage of Augustine's thought, who does not focus on confirmation but on personal faith. Certainly, it belongs to circles who opt for a lax praxis of admission (cf. Anon. ch. 17: "it will behove you, in whatever way you can, to aid even this man if he repent" - about a person who was initiated by a bizarre baptism ritual) such as the Marcionites had. Its stress on baptism in the name of Jesus (so not on the Trinitarian formula) might also indicate a backdrop in circles influenced by Marcionitism. Nevertheless, the writing is not in direct line with the Marcionites, because these practiced rebaptism. I would position the writing in one of those many groups that are in between Marcionitism and Catholicism in the third century, with elements from both traditions such as, for example Ad Diognetum (cf. Van de Beek, 2002). 
Cyprian certainly must have known this text, and thus can rightly claim that it is custom - at least in Africa. One must even wonder whether Augustine did not know it and consciously neglected it.

It appears that in Africa it was normal to baptise heretics, and that the issue burned again in the 250s when bishops and presbyters in that region were influenced by Rome and its different custom. Stephen was a person who wanted to push his format on other regions of the church (cf. Firmilianus, Epistola 74.17, $25=$ CCSL 75. $17.1 \mathrm{ff}$. and 25; Dionysius of Alexandria, Letter to Xystus, Bienert, 1972:38), and of course, these regions had to respond, if they were not also urged to do so by the ongoing entry of heretics into the Catholic Church.

Africa continued its own theology regarding baptism after the conflict between Cyprian and Stephen. In the fourth century, Optatus of Mileve (who died about 387) maintained that heretics must be baptised. Optatus was not an adherent of the Donatists, who were condemned in Arles. On the contrary, he contested them and was one of the champions of the Catholic Church. Optatus differentiates between schismatics and heretics. Schismatics have true faith and thus a real baptism, while the baptism of heretics is of no value. The latter must be baptised when they become Christians. Optatus agrees with the Donatists that heretics have false baptism, and that they rightly "closed the garden for the heretics" (Optatus, De schismate Donatistarum 5.12), because they are outside the Catholic sacraments (Optatus, De schismate Donatistarum 1.5). Thus, there are no sacraments among them at all (Optatus, 1.10). ${ }^{3}$

Optatus differs from Cyprian in his rejection of rebaptising schismatics. With regard to this, he is in line with the decisions of the ecumenical councils (see below). But he strictly keeps to the rejection of the baptism of heretics. Augustine's position is, therefore, at least in North Africa, a novelty, propounded so shortly after Optatus' rejecttion of the baptism by heretics.

\section{Cappadocia}

In his conflict with Stephan of Rome, Cyprian sought support from Cappadocia. The bishop of Ceasarea, Firmilian, responded to him in a letter, wherein he explains that the churches in that region continue to baptise heretics who turn to the Catholic Church (Cyprianus,

3 To consider the issue of Optatus more extensively, see Ernst (1901:43-52). 
ANF, Epistola $74=$ CCSL 75). They confirmed this practice at synods in Iconium (Firmilianus, Epistola 74.7, $19=$ CCSL 75.7.5 and 19.4) and Synnada (Dionysius, Letter to Philemon, Bienert, 1972: 40). According to Firmilian, it has always been custom in the church to do so. Thus, when Stephen calls on custom against Cyprian and the bishops of the East (Firmilianus, Epistola 74.19 = CCSL 75.19.13; cf. Augustinus, De baptismo 5.23.31; 25, 36), the argument does not fit. Firmilian, knowing he is supported by preceding synods in Asia, strongly confirms Cyprian's position - even more because of Stephen's threat of excommunication. Firmilian's letter is fierce; he compares Stephen to Judas (Firmilianus, Epistola $74.2=$ CCSL 75.2.3). If Stephen excommunicates all the others because they baptise heretics, who actually is then schismatic? (Firmilianus, Epistola 74.24 = CCSL 75.24.2). Is it not the bishop of Rome who breaks the unity of the church?

It is interesting to look closely at two aspects in Firmilian's letter. First, he speaks about baptising heretics as such. At the Synod of Carthage in 256 some bishops made a distinction between people who became heretics by leaving the church and those who were baptised in the heretical communities themselves (Cyprianus, Sententiae episcoporum 8 and 45). The former were not baptised, because this would have been a real rebaptism and thus a denial of the previous baptism; that is impossible because it is the baptism of the Catholic Church. Firmilian does not refer to this distinction. However, that does not mean he did not know it and practice it. Many bishops at the synod of Carthage also speak about baptism of heretics indiscriminately, without that a discussion arises with those who make this distinction. It could have been self-evident for them and also for Firmilian.

More interesting is the list of heretics who must be baptised as put forth at the synod of Iconium. The most remarkable of those listed are the Cataphrygians, i.e., the Montanists (Firmilian, Epistola 74.7 $=$ CCSL 75.7.3). One must wonder whether Africa had the same practice. It is generally known that Tertullian became a Montanist. That did not prevent the ultra-Catholic Cyprian from reading him intensively and calling him "the master" (Hieronymus, De viris illustribus 53). Cyprian and the whole African theology of the third century strongly rely on Tertullian's thought (Mohrmann, 1951:C; Faber, 1969:1). That would hardly be understandable if they saw him as a heretic. Therefore, the more recent research which considers Tertullian's relation to Montanism in the perspective of sympathy rather than as really leaving the orthodox church is convincing (cf. Vokes, 
1966; Ayers, 1976; Bray, 1979; Von Campenhausen, 1984; Barnes, 1985). Even Montanism, as such, could have had the appearance of a movement rather than a counter-church.

In Asia it might have been different. Phrygia was the cradle of Montanism, and so Firmilian labels them as "Cataphrygians". In that region they might have been a real threat for the church and her integrity. The explicit reference that the customary rejection of heretical baptism was "confirmed in Iconium, which is a place in Phrygia", seems to refer to this (Firmilianus, Epistola $74.7=$ CCSL 75.7.5). This would imply that exclusion of specific groups not only has to do with their thought, but also with the impact they had on the church. The Montanists jeopardised the very integrity of the church in Asia, just as the Novatians did in Africa. By consequence, the Asian church took firm action against the Montanists, while Cyprian was solidly against the Novatians. 4

A letter of Basilius confirms these different dealings with Montanists. He reports that the church decided to not acknowledge their baptism, and he is amazed that Dionysius of Alexandria overlooked this decision and accepted their baptism (Basilius, Epistola 188.1). Therefore, in Egypt they were admitted to the church without baptism. That would be in line with obvious use in Carthage. 5 Dionysius did not see the Montanists as heretics. Otherwise he would have required them to be baptised (see below), as his contemporary colleague in Caesarea and the later Basilius did. 6

The situation in Asia is clear: they are just as strict as Africa or, in some aspect, even stricter than their brothers overseas. When Augustine writes about a mere correspondence with some bishops "in far distant lands beyond the sea", he plays down the clear evidence of a solid tradition in Asia that he knew very well from Firmilian's letter, whereto he refers.

$4 \quad$ On the Novatians, also see Ernst (1901:9).

5 When Bienert (1978:188) thus states: "It is therefore not possible to rank Dionysius into one of both conflicting parties - the Roman or the African", he precisely misses the point that Africa dealt differently with the Montanists than Cappadocia. Dionysius is fully in line with Africa, except in his opinion on schismatics.

6 That the difference between schismatics and heretics was decisive is well shown by Basil's different dealing with the Encratites: after he saw them as heretics, he no longer accepted their baptism (Ernst, 1901:31). 


\section{Syria}

The data about the issue in the Syrian church are few. Most clear are the Canones Apostolici (Funk, 1905). In this writing from the late fourth century, it is ordered: "Those that are either baptized or ordained by [heretics], can be neither Christians nor clergymen" (canon 68.) The Apostolic Constitutions elaborate this more extensively:

Be likewise contented with one baptism alone, that which is into the death of the Lord; not that which is conferred by wicked heretics, but that which is conferred by unblameable priests, in the name of the Father, and of the Son, and of the Holy Ghost: and let not that which comes from the ungodly be received by you, nor let that which is done by the godly be disannulled by a second. For as there is one God, one Christ, and one Comforter, and one death of the Lord in the body, so let that baptism which is unto Him be but one. But those that receive polluted baptism from the ungodly will become partners in their opinions. For they are not priests. For God says to them: Because you have rejected knowledge, I will also reject you from the office of a priests to me. Nor indeed are those that are baptized by them initiated, but are polluted, not receiving the remission of sins, but the bond of impiety. (Funk, 1905:6.15, 1-3.)

The passage is, except from the first phrase (here in italics), not found in the earlier Didascalia, which, of course, does not mean that it was not practiced at that time. It could also not be a matter of debate and reflection because it was generally accepted. As Ernst (1901:36) states, the argumentation is close to Cyprian's. Only blameless priests of the Catholic Church can administer baptism. This is the praxis of both Africa and Cappadocia, and Syria seems to not differ from them.

A document that gathers earlier materials from the praxis of the church, as the Constitutions are, is very helpful for the understanding of a tradition. Thus, although we do not know much about Syria, it is more probable that they had the same praxis as Asia, to which they had close relations, than that they were of the same opinion with Rome.

\section{Egypt}

The position of Egypt is complicated. That is mainly due to some letters sent by Dionysius of Alexandria to successive bishops of Rome, and to some others. The problem is that we have only frag- 
ments of these letters - some by Eusebius of Caesarea in his History of the church, others in Armenian and Syrian versions, that partly overlap in some cases (for the text, see Bienert, 1972:37-45). It is always uncertain what the context of the fragments was and whether the author who uses them does not make a selection for his own ends and leaves out what did not suit him. Next to that, the authenticity of some fragments is a matter of debate.

An important letter by Dionysius is written to Stephen of Rome. Fragments are left in all three versions. The main message of the letter is that the churches in the East have come to peace after the confusion caused by the Novatians (Eusebius, Historia Ecclesiastica 7.4). It is the final section of a letter regarding the baptism controversy. Dionysius says to Stephen: "Now that we have found peace, please, do not interfere in our matters of how we deal with heretical baptism by which you would make new troubles." Certainly, the churches in the East would not fall into line with Rome. The tone in the letter of Firmilian to Cyprian is not that of someone who is on the brink of giving in. Even more excluded is the idea that a decision of several synods in Asia could be changed only by a letter from Rome in that time (cf. Dionysius, To Philemon, Bienert, 1972, $39 \mathrm{ff}$.). Thus, by pushing forward his ideas, Stephen would cause new troubles.

On the other hand, it would be premature to conclude that Alexandria also lined up with the Cappadocians and the Syrians. What was the use in Egypt as expressed by Dionysius? There is at least one clear statement on the topic: people who have been baptised within the church and who subsequently become heretic, and then return again should not be rebaptised (Dionysius, To Philemon, Bienert, 1972:39 ff.). That is even more the case with those who only had heretical sympathies and contacts with the heretics, but did not break unity with the church (Dionysius, To Philemon, Bienert, 1972: 40). Cyprian would agree with this. The fact that Dionysius explicitly mentions that those who return to the church should not be baptised "because they before received the holy from him" (i.e., the Catholic bishop Heraklas) is an indication that it is different with those who never belonged to the church (Dionysius, To Philemon, Bienert, 1972:40).

In another passage, he says heretics must be baptised and schismatics not (To Dionysius and Stephen, Bienert, 1972:42). The authenticity of this passage is contested (Bienert, 1972:111, note 75), but it could be a summary of ideas that we find in the other texts of Dionysius. He frequently refers to those who do not speak 
correctly about God and the other core issues of the creed. Those people cannot be accepted. This has not only to do with the Trinitarian baptismal formula as Augustine argues, but with the content of the faith in the specific community. Even if they baptise in the name of the Father, the Son, and the Holy Ghost, they are not baptised if that happened in a community that did not have the right confession about the Trinity, the work of Christ, and the resurrection (Dionysius, To Stephen, Bienert, 1972:42, 43 ff.; To Xystus 3, Bienert, 1972:45).

This is in line with remarks made by Origen and Clemens of Alexandria. Dionysus was a great admirer of Origen, and he would not easily disagree with him. There are two passages in Origen's Commentary on John that, more or less, indirectly refer to baptism by heretics. The most explicit statement is: "he who receives the Spirit abiding on Jesus Himself is able to baptize those who come to him in that abiding Spirit" (Origenes, 6.25). Those who did not receive the Holy Spirit cannot be true believers, "for how can anyone be said in the full sense to believe the Scripture when he does not see in it the mind of the Holy Spirit, which God would have us to believe rather than the literal meaning?" (Origenes, 10.27). Only in the fullness of faith in Scripture as given by the Spirit can we administer baptism "for faith in its full sense is the act of him who accepts with his whole soul what is professed at baptism" (Origenes, 10.27). The profession of faith is the belief in the Trinitarian God. The one who denies the Father, the Son, or the Spirit is excluded from the fullness of faith. He has not received the Spirit, and thus he cannot baptise.

Now Origen (6.17) makes a similar distinction as Augustine did:

It is to be observed that while the four [Gospels] represent John [the Baptist] as declaring himself to have come to baptize with water, Matthew alone adds the words to repentance, teaching that the benefit of baptism is connected with the intention of the baptized person (6.17).

It seems that there is a difference between baptism with water and its benefit through faith, so that one just like Augustine could argue that if a person is baptised by water, only the true faith should be added by receiving the Spirit. Origen himself, however, does not draw this conclusion. He continues: "Those persons in the Acts who were baptized to John's baptism and who had not heard if there was any Holy Ghost are baptised over again by the Apostle." (Origenes, 6.17.) Thus, the one who did not receive full baptism must be 
baptised again, now within the community of the Spirit. We can conclude that, according to Origen, heretics who "do not accept with their whole soul what is professed at baptism" must be rebaptised, just as the disciples of Apollos in Ephesus.

We must, however, take in consideration that these passages come from a commentary on the baptism of John the Baptist. That might imply that the interpretation is more directed at the Jews, who still are "before" Christ, just as John himself is, than against heretics. Jews were more numerous in Alexandria in that time than Christians and thus always present in the life of the church. On the other hand, Origen directs himself to the Christians, and they are his primary audience; thus his vision also has consequences for their thought: without the Spirit there is no baptism, and there is no faith without a full understanding of its Trinitarian content.

Clement seems to express the same idea in his single remark on heretical baptism in a comment on Proverbs 9:17: "Then He subjoins: For so shall you pass through the water of another; reckoning heretical baptism not proper and true water" (Clemens, Stromata 1.19). The conclusion is clear: those who are baptised by heretics are not baptised at all, because you cannot be immersed in and washed by water that is not real water.

It appears that Dionysius operates in the line of his predecessors and rejects the baptism of heretics. At the least he disagrees with Stephen that the bishop of Rome could impose his view on all other bishops. Dionysius says several times that we should leave the decision about baptism to the local bishops, and he does not want to interfere in the affairs of the bishops in Iconium because that could cause hatred and conflicts (Dionysius, To Philemon, Bienert, 1972: 40; To Stephen, Bienert, 1972:42, 44). That suggests a disagreement between him and the Cappadocians. We must, however, precisely read the text in order to see what is at stake here. Dionysius says that if it is about the acceptance of people, it should be left to the local bishops. One must distinguish between the general rule and its implementation with people. The former must be clear among all churches, bishops, and presbyters. "In the most central and important questions we must be hard" (Dionysius, To Stephen, Bienert, 1972:42, 44). 7 We cannot negotiate about the core issues

$7 \quad$ When Bienert (1978:187-193; cf. also Bouma, 1943) argues that Dionysius sought for a compromise between Rome and others, he does not take 
of faith. Heretics are dead and are excluded from the life in Christ that is within the church. The decision whether someone personally should be considered as a heretic is a matter for the bishop (Dionysius, To Stephen, Bienert, 1972:42, 44). That could also imply that there can be a discussion about the question of whether a group is heretical or not. Gnostics, Marcionites, and other people who do not confess the basics of the creed surely are heretics, but for example, about Novatians and Montanists you can be of different opinions. That can even differ in the local situation, depending on the extent of extremism and impact of specific topics of sidetracks in the tradition of faith in a specific region.

Dionysius refers in his argumentation to custom. What he says is not a mere finding of some bishops in his own century. When they exclude heretics, he is convinced this is in use since the time of the apostles and thus required for everyone. Other customs are of no value if they are different from the apostles' use (Dionysius, To Stephen, Bienert, 1972:43). This is written in his letter to Stephen wherein he tells about the peace in the East. He says to Stephen: let us keep to this traditional use and do not make problems in a case that has been settled for a long time. Be hard on heretics and leave it to us do decide which people are indeed heretics - and that is not a matter of mere discipline but about the true doctrine of God, wherein you also cannot negotiate.

Eusebius mentions another letter by Dionysius (Historia ecclesiastica 7.9.6). It is a pity that this letter to Xystus of Rome has not survived because, according to Eusebius, it was, an extensive investigation on the topic. That Dionysius intensively struggled with heretical baptism is clear from the information that Eusebius gives us from the letter to Xystus. Dionysius tells about a man who was a heretic and now belonged to the church (Dionysius, To Xystus, Bienert, 1972:41). He participated in the communion and prayer. Only later he discovered that the baptism of heretics was of no value. He refused to participate any longer unless he was baptised. What to do in such a case - he already frequently received communion, and now he wants to be baptised? Dionysius describes the problem to Xystus. Of course, the bishop of Alexandria does not write to the bishop of Rome about a decision for an individual person. It is a case study about policy, and it seems to ask the question: can you

Dionysius' own position seriously enough. Certainly, he tries to restore peace, but that is different than compromise. 
be as strict as Rome is and excommunicate everybody who administers rebaptism?

We can conclude that Dionysius defended the baptism of people who came from the heretics. He thought in line with his Alexandrian predecessors and with his colleagues in Carthage and Cappadocia. This is confirmed by Hieronymus who writes about Dionysius: "He wrote a lot of letters to several persons in consent to the rule of the synod of Cyprian and Africa about the rebaptism of heretics". (Hieronymus, De viris illustribus 69). The opinions about schismatics could differ and even about the question who was to be considered as a heretic, but that was even the case between Carthage and Cappadocia. Alexandria, Carthage, and the East are much closer to each other than to Rome. Rome really assumes a different position.

\section{Rome}

When we summarise, it will be clear that Augustine's argument of custom is not as solid as he claims and that Stephen's appeal to custom seems to be merely Roman custom. We must, however, look more precisely into the baptismal tradition of Rome. With regard to this a remark by Hippolytus in his Philosophumena is extremely interesting. It is about the Roman bishop Callistus ( \pm 218-223). Hippolytus writes: "Under this [Callistus] a second baptism has been ventured upon by them for the first time" (Hippolytus, Philsophumena. 9.12.26). Thus it seems that in Rome itself rebaptism was administered in the time before Stephen.

Most discourses on heretical baptism do not pay attention to this account of rebaptism, and those who do so play it down. So Legge (1921:132), who translated the Philosophumena, says that Cyprian and Firmilian certainly would have used it if there would have been even a slight indication of rebaptism in Rome itself. This seems convincing. Thus the passage can be skipped for research. 8 not accuse Callistus of teaching" "this practice of second baptism", but only "that it was begun in his time". Hippolytus, however, says explicitly: "These things [are] the most amazing Callistus has set on foot". See also Chapman (1908:184): "Hippolytus also declared that rebaptizing (of heretics) was performed first in Callistus's day, but he does not state that Callistus was answerable for this." Chapman strongly defends Callistus. All these studies follow Döllinger (1853:189 ff.) who states that Hippolytus will only say that in the time of Callistus elsewhere rebaptism of heretics began. 
That is, however, only the case if we neglect its context. If we take that context into account, perhaps it turns out to be the key to understanding the whole conflict.

Hippolytus makes his remark in the context of abuses that occurred during the episcopacy of Callistus. While in the East and Africa the church still struggled with a second penitence, he admitted anyone to the communion. ${ }^{9}$ Even murderers and prostitutes were accepted for penitence and admitted to the Eucharist. In the section that just precedes the sentence on rebaptism, Hippolytus reports that unmarried women slept with many men and when they became pregnant they provoked abortion, thus "committing both fornication and murder", as he says (Hippolytus, Philosophumena 9.2.12). And then follows his remark on rebaptism: people with this kind of behavior were baptised once again. That means that it is not at all about the baptism of heretics, but about rebaptising heavy and perverse sinners. After a dirty life they were washed once again, cleaned from sin, and accepted as pure members of the church, just as they were after their previous baptism. Tertullian writes a whole treatise, On modesty, on Callistus' practice. "Come, now, let them ... teach us the possibility that the stains of a flesh which after baptism has been repolluted, can by repentance be washed away." (Tertullianus, De pudicitia 12.1; cf. also 16 and 22.)

Such a rebaptism would have been rejected by Cyprian as well, of course. He would have conceived it as a real rebaptism, so that the church was not only polluted by the life of those people, but also by a denial of their former baptism.

That Hippolytus means such a kind of rebaptism is also clear from what follows. There he describes the Elkaisites who also practiced a repetition of baptism (Hippolytus, Philophumena 9.3.13). For them

9 Cf. Tertullian: (Tertulliaus, De pudicitia 1.6-8.):

The Pontifex Maximus - that is, the bishop of bishops - issues an edict: I remit, to such as have discharged (the requirements of) repentance, the sins both of adultery and of fornication. $O$ edict, on which cannot be inscribed, Good deed! And where shall this liberality be posted up? On the very spot, I suppose, on the very gates of the sensual appetites, beneath the very titles of the sensual appetites. There is the place for promulgating such repentance, where the delinquency itself shall haunt. There is the place to read the pardon, where entrance shall be made under the hope thereof. But it is in the church that this (edict) is read, and in the church that it is pronounced; and (the church) is a virgin! Far, far from Christ's betrothed be such a proclamation! 
baptism was similar to Jewish washing rituals that were repeatedly done for the believers in order to keep them clean. Callistus' practice is like that: he cleans the sinners who committed heavy sins after their first purification in baptism. For him baptism is not dying to the old life and the insertion into the one and holy body of Christ as a definitive transfer to a new life, but a mere rite of purification that can be repeated, if a new cleaning is required. Tertullian gives his, as usual mordant, judgment on this practice:

Who will fear to squander what he has the power of afterwards recovering? Who will be careful to preserve to perpetuity what he will be able to lose not to perpetuity? Security in it is likewise an appetite for it. Therefore the apostate withal will recover his former garment, the robe of the Holy Spirit; and a renewal of the ring, the sign and seal of baptism; and Christ will again be slaughtered. (Tertullianus, De pudicitia 9.11.)

If this practice entered into a Roman's mind in the days of Stephen, we can imagine how upset sincere people became by the very word rebaptism. Thus Stephen could not accept it because of his own Roman church. At the very moment he would do so, he would be labeled as a second Callistus and people would certainly go en masse to the very strict Novatians. He could not even say that it could be left to the wisdom of a local bishop because any bishop who would accept such practices should be removed from the holy church of Christ.

The situation in Rome was even more precarious. Epiphanius tells that Marcion also introduced rebaptism in Rome (Epiphanius, Panarion 3.42; Williams, 1987:210, 272-274), and he did so similarly to Callistes - as a new cleaning of Christians who had committed heavy sins. Marcion even baptised three or more times. Marcion taught a loving God. His God was not angry and wrathful. He would not condemn any sinner. A new beginning was always possible (first of all, for Marcion himself, as Epiphanius tells, because Marcion had sexual relations with a girl), and thus a new cleansing by a new baptism. Thus, the praxis of Callistus is Marcionite use. When Stephen accepts even Marcionites without baptising them when they come to the Catholic Church (Cyprianus, Epistola $72.4=$ CCSL 73.4.1 ff.; Epistola 73.7 ff. = CCSL 74.7.3; 8.2), he precisely distinguishes himself from Marcion. If he would have baptised the Marcionites, they would have understood this rebaptism totally wrong. They would have concluded that it was a repetition of baptism as a practice of laxity such as Marcion himself taught and Callistus introduced even in the Catholic Church. 
If we look at the conflict from this perspective, some particularities of the letter that Stephen sent to Cyprian and Firmilian become clear. Cyprian (Epistola 73.4 = CCSL 74.4.1) reports that Stephen argued that the heretics did not require rebaptism either. Cyprian immediately reacts: since when are the heretics an example for our practice? If we, however, keep Stephen's position in mind, it is about something else. Heretics, of whom the Novatians where the most conspicuous in Rome by that time, accepted Catholic people who came to them without baptising them. That means they accepted them as Christians. They saw them in the unity of Christ. Then we can do the same, making the gap between Catholics and Novatians as small as possible. The closer Stephen was to the strict Novatians and the more he could claim them as related, the less the strict and sincere people in Rome would be inclined to join them because their own bishop was also a serious man. Both the Novatians and Stephen and his Catholic Church wanted to live according to the calling of Christ, and baptism was the moment of transfer to that reality. They have the bind with Christ in common, and therefore a new baptism is not required, especially if such a second baptism would imply that it was minimised to a mere washing ritual. When Stephen thus speaks about baptism and Christ, it is not in the meaning that Augustine lays in his words: that baptism is owned by Christ and thus independent from the administrator, but that we are owned by Christ through baptism and living in a community where his name is holy and where people want to follow Him, both among Novatians and among Catholics.

If this is the backdrop of Rome's resistance against rebaptism, it is also clear why Cyprian could not use it to make his point. The last result that he could want is to be connected in any way with Callistus and his rebaptism. That was not only opposed to his sincerity, but would also be a mighty weapon in the hands of the Novatians.

Stephen's position was not a mere power play as bishop of Rome. He had to keep his church clean from sins such as those that were accepted by Callistus. He could not use his proper argument against the Africans who, first of all, would blame the church of Rome because of their former laxity and, next to that, tell that their rebaptism is of a different kind: Rome had introduced a real rebaptism and thus perverted the Catholic baptism; Africa only rejects the perverse ritual of heretics in baptism and thus strives for the purity of the church.

This finally brings Stephen close to the camp of the Novatians. His aim is to have a pure church, not maculated as in the days of 
Callistus. Both his and the Novatians' focus is the ecclesia sine macula et ruga, while Cyprian's main point is the unity of the church. Certainly, he also wants a pure church and Stephen a united church, but their main focuses are different. Consequently, we find Augustine closer to Cyprian than to Stephen. He might formally share Stephen's rejection of rebaptism, but also for him, unity is his main goal against the Donatists who opted for a church without spot or wrinkle.

Maybe the conflict would not have had so great an impact if Rome and Carthage would have had similar distance such as Phrygia and Carthage. The latter couple could cope with a different praxis with regard to the Montanists, but Rome could not cope with a different praxis for the Novatians, even more because there was no language barrier here. Accepting the African practice would imply accepting it for Rome as well, and then the phantom of Callistus would soon appear.

\section{Preliminary conclusion}

By summarising, the following positions become clear:

- Rebaptism of people within the Catholic Church is rejected by all. That Callistus once introduced this practice is so abject that everybody prefers to be silent about it.

- Many documents are silent about rebaptising people who were baptised in the church, subsequently became heretics, and then returned to the church; but those who deal with it explicitly reject it. Baptism is one as Christ is one and cannot be repeated. It is not far-fetched to suppose that this was the common opinion.

- The Alexandrian church seems to have accepted schismatics without baptising them. Carthage did not do so, and the sources of the East are silent on this point, although the tone of the correspondence of Cyprian and Firmilian gives at least the impression they also agreed on this point. Rome accepted schismatics without baptising them.

- Africa and the whole East rejected the baptism of heretics, and thus they must be baptised when coming to the church, although it is debatable who is a heretic. At least those who belong to a group which denies the core elements of the creed, especially the doctrine of the Trinity, are heretical, but the others are left to the local bishops. 
- Rome accepts any heretic, even Marcionites, without baptism. They cannot cope with the very idea of rebaptism due to their own recent history.

- Augustine restricts the Roman practice: the formula should at least be Trinitarian. Next to that, he breaks the bind between the ritual and its effects. His vision has become law in the West with a call on the synod of Arles, though Arles probably did not mean that the mere formula would be sufficient, but the content should be accorded as well.

\section{Councils}

The synod of Arles brings us to Augustine's last argument: now that a universal council has decided the issue, we no longer are free in our opinion as Cyprian still was, but we have to submit ourselves to the discipline of the church.

Of course, Augustine is right that Arles forbade rebaptism of heretics, although the latter is probably interpreting the Trinitarian formula less formally. But can we label Arles as a universal council as Augustine does? ${ }^{10}$ It was only a council of the West and a political instrument against the African Donatists. We could name it universal if a later council, for example Chalcedon, would have accepted it as such, or even so if a later, more universal council had not decided differently. Both are not the case. In none of the later ecumenical councils was the decision of Arles authorised. On the contrary, they made different decisions.

Canon 19 of the first council of Nicaea decrees that "Paulianisantes" must be baptised when they come to the Catholic Church (Denzinger, 1967:128). The name Paulianisantes is derived from Paul of Samosata who had an unorthodox Christology. It must be noted that it is Paulianisantes, not Paulianoi. That means it is not about clear followers of Paul of Samosata, but those who think similar to Paul or have Paulinist sympathies. That actually covers all those people who have an unorthodox Christology. Athanasius draws the conclusion that Arians should be baptised when coming to the Catholic Church:

10 That Augustine knew about a council that decided to forbid rebaptism of heretics, but did not know which council that would be, as Ernst (1900) argues, is really far-fetched and can only be explained by Ernst's longing to hold the church father in positive regard. 
For the Arians do not baptize into Father and Son, but into Creator and creature, and into Maker and work. And as a creature is other than the Son, so the Baptism, which is supposed to be given by them, is other than the truth, though they pretend to name the Name of the Father and the Son, because of the words of Scripture. For not he who simply says, 'O Lord', gives Baptism; but he who with the Name has also the right faith. On this account therefore our Saviour also did not simply command to baptize, but first says, 'Teach', then thus: 'Baptize into the Name of Father, and Son, and Holy Ghost', that the right faith might follow upon learning, and together with faith might come the consecration of Baptism. (Athanasius, Contra Arianos 2.42; cf. also 2.41, 43.) ${ }^{11}$

By excluding the Pauliniasantes from real baptism the council followed Dionysius' view that acceptance of baptism has not only to do with the Trinitarian baptismal formula as Augustine argues, but with the content of faith in a specific community. The Paulinians baptised in the name of the Father, the Son, and the Holy Spirit (Athanasius, Contra Arianos 2.43; Ad Serapion 1.30), but they did not have true faith in Christ.

On the other hand, the Council decided that Novatian bishops could be accepted by imposition of hands (canon 8, Denzinger \& Schönmetzer, 1967:127). ${ }^{12}$ That implies, of course, that their baptism is accepted as well - in contrast to the Paulianisantes, who only could regain their office after being baptised (can. 19).

The decisions of Nicaea are not merely about these two specific groups. They display a policy that was present in Alexandria: accepting schismatics and baptising heretics. 13 The council of Constantinople (381) confirms this track. When the symbolum says "one baptism for the remission of sins" (Denzinger \& Schönmetzer, 1967: 150) the term "one baptism" has become a technical term: there is

11 Cf. also Irenaeus' stress on the Trinitarian baptism (Irenaeus, Epideixis 4, 9) and his abhorrence of all other kinds of baptisms (Irenaeus, Adversus haereses $1.21 .3 ; 1.23 .5)$. Though he does not explicitly reject the baptism by heretics, the conclusion can hardly be otherwise.

12 Obviously, this is not the imposition of hands for the reacceptance of sinners into the church, but the inauguration ritual of bishops (cheirotomenous autous menein houtōs en tōi klèrōi).

13 When Neunheuser (1983:58) therefore states that the council of Nicaea, just like Arles, took on a "neutral" position, this does not fit to either of the synods. 
only one baptism of the Catholic Church and the baptism of heretics is not acknowledged. The text of the creed is probably derived from the creed of Cyrillus of Jerusalem, and he explicitly indicates in his commentary on the creed what this means for the baptism of heretics:

We may not receive Baptism twice or thrice; else it might be said: 'Though I have failed once, I shall set it right a second time', whereas if thou fail once, the thing cannot be set right; for there is one Lord, and one faith, and one baptism: for only the heretics are re-baptized, because the former was no baptism. (Cyrillus, Lectiones Catecheticae, Proemium, 7.)

This is fully in line with what Basil the Great writes on the baptism of heretics (Epistolae 188.1). It is clearly generally accepted in the East.

Thus both ecumenical councils of the fourth century order the baptism of heretics and Nicaea accepts schismatics without baptism, while Constantinople is silent on this point. Therefore, Augustine is wrong when he states that a universal council forbids baptising heretics. Arles does so, but that can hardly be called universal compared to Nicaea and Constantinople. By consequence, Augustine's argument turns against himself: if an ecumenical council has decided, you must submit to that decision.

\section{Conclusion}

The mainline of early Christianity is to baptise people who come from heretical communities. Cyprian was very strict by also rejecting the baptism of schismatics, but the ecumenical councils in the fourth century kept the Alexandrian policy. The Orthodox Churches generally followed this practice (Wendebourg, 2001:943). The West followed Rome in also accepting heretics, however with the restriction that the Trinitarian formula was used. The extremely formal interpretation of this rule by Augustine is really new and has to do with arising individualism in his days, whereby rite and faith are separated. This is different from the time before him when baptism was taken very seriously. That is even the case for Stephen, who rejected any rebaptism in order to prevent his people from living in severe sins or leaving the church to join the Novatians.

The separation of the ritual and the salutary effect of baptism by Augustine is a signpost on the way of Western church history. The Roman Catholics stressed the formal aspect; the protestants, and especially the reformed churches, paid much attention to personal 
faith. Faith (understood as personal conviction) became decisive, and since there are as many convictions as there are human beings, the door was open to create your own community. As a consequence, the reformed tradition can only speak about churches in the plural. Cyprian would ask: "Can that be the church of the one Christ?"

\section{List of references}

ANON. De Rebaptismate. MPL 14 3:1255-1268. Turnholt: Brepols.

ATHANASIUS. Ad Serapion 1. Paris: Éditions du CERF. (Sources Chrétiennes, 15.)

ATHANASIUS. Contra Arianos 2. MPG 15 26:145-322. Turnholt: Brepols.

AUGUSTINUS. De baptismo. MPL 43:107-244. Turnholt: Brepols.

AYERS, R.H. 1976. Tertullians paradox and contempt for reason reconsidered. Expository times, 87:308-311.

BARNES, T.D. 1985. Tertullian: a historical and literary study. 2nd ed. Oxford: Clarendon.

BASILIUS. Epistolae. MPG 32:219-1112. Turnholt: Brepols.

BIENERT, W.A. 1972. Dionysius von Alexandrien: das erhaltene Werk. Stuttgart: Hiersemann. (Bibliothek der Griechischen Literatur, 2.)

BIENERT, W.A. 1978. Dionysius von Alexandrien: zur Frage des Origenismus im dritten Jahrhundert. Berlin: De Gruyter. (Patristische Texte und Studien, 21.)

BOUMA, S.J. 1943. Dionysius van Alexandrië. Purmerend: Muusses.

BRAY, G.L. 1979. Holiness and the will of God. London: Marshall, Morgan \& Scott.

CHAPMAN, J. 1908. Callistus 1. (In The Catholic Encyclopedia. Vol. 3. New York: Appleton. p. 183-185.)

CLEMENS, A. Stromata 1. Paris: Éditions du CERF. (Sources Chrétiennes, 30.)

CYPRIANUS. Epistolae, CCSL 16 3B. Vindebonae: Geraldi Filium Bibliopolam Academiae.

CYPRIANUS. Sententiae episcoporum. CCSL 3E. Turnholt: Brepols.

CYRILLUS. Catechetical lectures. MPG 33:331-1028. Turnholt: Brepols.

DENZINGER, H. \& SCHÖNMETZER, H. 1967. Enchiridion symbolorum definitionum et declarationum de rebus fidei et morum. 34th ed. Barcinone: Herder.

DÖLLINGER, J. 1853. Hippolytus und Kallistus oder die Römische Kirche in der erste Hälfte des dritten Jahrhunderts. Regensburg: Muaz.

EPIPHANIUS. 1987. Panarion, ed. by Williams.

ERNST, J. 1900. Der hl. Augustin über die Entscheidung der Ketzertauffrage durch ein Plenarkonzil. Zeitschrift für katholische Theologie, 24:282-325.

MPL = Migne Patrologiae Latina

15

MPG = Migne Patrologiae Graeca

16

CCSL = Corpus Christianorum. Series Latina 
ERNST, J. 1901. Die Ketzertaufangelegenheit in der altchristlichen Kirche nach Cyprian mit besonderer Berücksichtigung der Konzilien von Arles und Nicäa. Mainz: Franz Kirchheim.

EUSEBIUS. Historia ecclesiastica. Paris: Éditions du CERF. (Sources Chrétiennes, 41.)

FABER, J. 1969. Vestigium ecclesiae: de doop als spoor der kerk (Cyprianus, Optatus, Augustinus). Goes: Oosterbaan \& Le Cointre.

FIRMILIANUS. Epistola ad Cyprianum. CCSL 97, Epistola 75. Turnholt: Brepols.

FUNK, F.X. 1905. Didascalia et Constitutiones Apostolorum. Paderborn: Schoeningh.

HIERONYMUS. De viris illustribus. MPL 23:602-720. Turnholt: Brepols.

HIPPOLYTUS. Philosophumena. Ed. by M. Marcovich. (Patristische Texte und Studien, 25.)

IRENAEUS. Adversus Haereses 1. Paris: Éditions du CERF. (Sources Chrétiennes, 264, tome 2.)

IRENAEUS. Epideixis. Paris: Éditions du CERF. (Sources Chrétiennes, 406.)

LEGGE, F. 1921. Hippolytus: philosophumena or the refutation of all heresies. Vol. 2. London: Society for Promoting Christian Knowledge. (Translations of Christian literature. Ser. 1.)

MOHRMANN, C. 1951. Apologeticum en andere geschriften uit Tertullianus' voor-Montanistischen tijd. Utrecht: Spectrum. (Monumenta Christiana, 1; Geschriften van de kerkvaders, 3.)

NEUNHEUSER, B. 1983. Handbuch der Dogmengeschichte. T. 4(2): Taufe und Firmung. Freiburg: Herder.

NOLET, W. 1926. Beknopt handboek der kerkgeschiedenis. 2e dr. Nijmegen: Dekker, Van de Vegt \& Van Leeuwen.

OPTATUS. De schismate Donatistarum. Paris: Éditions du CERF. (Sources Chrétiennes, 412-413.)

ORIGENES. Commentarius in Ioannem. Paris: Éditions du CERF. (Sources Crétiennes, 157.)

TERTULLIANUS. De baptismo. CCSL 1:277-295. Turnholt: Brepols.

TERTULLIANUS. De praescriptione haereticorum. CCSL 1:187-224. Turnholt: Brepols.

TERTULLIANUS. De pudicitia. CCSL 2:1231-1330. Turnholt: Brepols.

VAN DE BEEK, A. 2002. Marcionitism in "To Diognetus: a plea for Christians at the expense of Jews". Nederduitse Gereformeerde teologiese tydskrif, 43:593-605.

VAN DE BEEK, A. 2009. Cyprian on baptism. (In Bakker, H. \& Van Geest, P.J.J. Cyprian of Carthage: studies in his life, language and thought. Leuven: Peters. (Late antiquity: history and religion, 2.))

VOKES, F.E. 1966. Montanism and ministry (In Cross, F.L., ed. Studia Patristica. Bd. 9: Texte und Untersuchungen zur Geschichte der altchristlichen Literatur, 94. Berlin: Akademie Verlag. S. 306-315. )

VON CAMPENHAUSEN, H. 1984. Tertullian. (In Greschat, M., Hrsg. Gestalten der Kirchengeschichte: Alte Kirche. T. 1. Stuttgart: Kohlhammer. S:97120.)

WENDEBOURG, D. 2001. Ketzertaufe in RGG ${ }^{4}$ 4. Tübingen: Mohr Siebeck.

WILLIAMS, F. 1987. The Panarion of Epiphanius of Salamis. Book 1. (Sect. 146). Leiden: Brill. 


\section{Key concepts:}

early church history

heretical baptism

rebaptism

\section{Kernbegrippe:}

herdoop

ketterdoop

vroeë kerkgeskiedenis 
